\title{
UNDERLINGE VERHOUDING VAN SKRIF EN BELYDENIS
}

\section{Inleiding}

Dat die vraagstuk waarmee ons hier te doen het tans van die uiterste aktualiteit is in die Christelike kerk sal vir elkeen wat enigsins op hoogte is met die kerklike en teologiese diskussie van ons tyd, met die eerste oogopslag duidelik wees. Berkouwer het in sy geskrif "Verontrusting en Verantwoordelikheid" ten opsigte van die defensief en die offensief in die kerklike stryd rondom die huidige verontrusting in Nederland verklaar dat daar in ons tyd meer en meer aarselinge en vraagtekens in die plek kom van vroeëre stellighede en uitroeptekens. Die kerk hou hom meer besig met vrae as om te leef uit 'n duidelike antwoord. In sy optrede weerspieël die kerk die onsekerheid wat buite sy mure heers. In alles kan daar 'n duidelike indikasie gesien word van 'n voortgaande relativeringsproses, 'n problematisering van sake sodat daar op die duur niks meer seker en onaantasbaar blyk te wees nie. ${ }^{t}$

Hierdie sinjalering van die kerklike situasie in Nederland geld onder andere en in geen geringe mate nie van ons onderhawige onderwerp. Vandaar dat dit in die sentrum van diskussie staan. Dit geld ook nie net in kringe waar die $19 \mathrm{e}$ eeuse modernistiese of $20 \mathrm{e}$ eeuse eksistensialistiese teologie hoogty vier nie, maar dit geld in kringe wat allerweë en allerjare beskou is as ortodoks, behoudend en konserwatief. Ons noem net een voorbeeld. In sy opspraakwekkende "Cahier voor cle gemeente": „Kerk en Belijdenis" stel C. Augustyn die vraag aan die orde: "Is het waar, dat de strenge binding aan de belijdenis, zoals we die in Dordrecht vinden, typisch reformatorisch is ?2 As Augustyn na 'n breedvoerige historiese ondersoek eindelik moet kom tot beantwoording van sy vooropgestelde vraag, dan het hy wel geen duidelik geformuleerde antwoord nie, trouens, die vrae is dan grootliks vermeniguldig, maar hy verklaar tog: „Mens kan mijns inziens niet volhouden dat de drie formulieren van enigheid op het moment de eendracht der kerk in het geloof tot uitdrukking brengen ... Het lijkt mij het beste, om duidelijk te zeggen dat de drie formulieren van enigheid hun tijd gehad hebben... Zij gaven voor de zestiende eeuw weer, wat wezenlijk was voor het geloof. In de andere situatie, waarin de kerk nu staat, kan men er weinig mee doen". Hy bepleit verder geen binding aan 'n ou of nuwe belydenis nie. ${ }^{3}$ In dit alles gaan dit ten diepste om die verhouding van Skrif en Belydenis.

\section{Twee uiterstes: Biblisisme en Konfessionalisme}

Ten opsigte van die verhouding van Skrif en Belydenis was daar in die kerk steeds twee uiterstes. Die gesag en gebruik van Belydenisskrifte is van die kant van die Biblisisme bestry en selfs ontken. Uit vorige eeue kan genoem word sulke groepe soos die Sosiniane, Kwakers, Unitariërs, Rassionaliste, Doopsgesindes en selfs 
die Remonstrante. Vandag is daar nog velerlei sektes wat die standpunt handhaaf.

Dit gaan hier om 'n opvatting wat die algehele tersydestelling van alle menslike dogmas bepleit. Argumente van die kant van die Biblisisme is velerlei. Die dogmas sou dan die vrye interpretasie van die Bybel in die voortgang van die Teologie strem; dit sou vryheid van gewete en die reg van partikuliere oordeel in gedrang bring; dit sou huigelary, onverdraagsaamheid en bekrompenheid bevorder; dit sou verdeeldheid en verwarring in die hand werk; dit sou religieuse animositeit en die vloek van sektarisme instigeer en by wyse van reaksie roep dit dogmatiese indifferentisme, skeptisisme en onttrou na vore. ${ }^{4}$ Die simbole van die kerk is in die kringe van die Biblisiste veelal bestempel as 'n juk van menslike outoriteit, 'n nuwe pousdom in die vorm van gedrukte dokumente. ${ }^{5}$

In die sestiende eeu het die Doopsgesinde hierdie standpunt sterk ondersteun. Maar ook binne die Gereformeerde Kerke van Nederland, by name van die kant van die Remonstrante, het die beskuldiging gekom dat die Gereformeerdes deur die strenge handhawing van die Belydenis aan die gesag, die genoegsaamheid en die volmaaktheid van die Skrif te kort doen. ${ }^{6}$

Al die ou argumente teen die Belydenisskrifte is deur die Remonstrante weer opgehaal. A. D. R. Polman gee daarvan 'n breedvoerige opsomming. ${ }^{7}$ Hulle was vas oortuig dat die majesteit, waardigheid en outoriteit van die Heilige Skrif deur die menslike formuleringe meer en meer in gedrang kom en eindelik sou verval. In die tweede plek was hulle oortuig dat dit skadelik en nadelig sou wees vir die kerk, die konsensie en die verklaring en toepassing van die Heilige Skrif omdat deur die Formuliere by die agterdeur 'n tirannieke wet sou insluip waaraan alles getoets sou moes word. In die derde plek maak sodanige Belydenisse die deur wyd oop vir skeidings en skeurings, dit word skeldsmure tussen Christene tot skade van die ganse Christenheid.

Ondanks die sterk standpunt van die Sinode van Dordrecht en die Gereformeerdes daarna was hierdie standpunt in die begin van die eeu by baie in Nederland oorheersend. Hofstede de Groot was vir geen geringe mate nie hulle spreekbuis. Formuliergesag en Skrifgesag is deur hulle teenoor mekaar gestel en dan is onomwonde gekies vir laasgenoemde.

Met die eerste oogopslag skyn die Biblisiste 'n sterk saak te besit. Hulle wil immers uitsluitlik die Heilige Skrif aan die Woord laat en met tersydestellings van alle menslike dogmas aan die Bybelse leer vashou. Dit is egter nog geen garansie dat die evangelie van Jesus Christus suiwer weergegee word nie. Die geskiedenis leer dat ook die Biblisiste hulle eie filosofie daarop nahou en met hulle sogenaamde "Bybelse Teologie" hul eie gedagtes in die Skrif indra. ${ }^{8}$

Die ander uiterste in die verhouding var Skrif en Belydenis is die Konfessionalisme.

Die Konfessionalisme misken die betreklike gesag van die Konfessie, maak die Belydenis tot 'n prinsipieel onveranderlike vasstaande grootheid, gryp altyd terug op die letter van die Konfessie 
as wetsartikel en verloor daarmee die subordinasie van die Konfessie aan die Heilige Skrif uit die oog. ${ }^{9}$ Dit kom neer op 'n algehele oorskatting van die Konfessie of die dogma van die kerk, en kan daarom ook dogmatisme genoem word. ${ }^{10}$

Onwillekeurig kom veral die standpunt van die Roomse Kerk hier in die visier. Breed hoef ons nie op dié standpunt in te gaan nie. Die verhouding van Skrif en Belydenis wortel by Rome in sy kerkbeskouing. Op die Konsilie van Trente het Rome, teenoor die Reformasie met sy „Sola Scriptura”, uitgespreek dat die waarheid vervat is in die geskrewe boeke $e n$ in die ongeskrewe oorleweringe wat van Christus deur die apostels of van die apostels self tot ons gekom het. Wat die kerk met onfeilbare gesag in latere eeue afgekondig het, het reeds in kiem in die oorspronklike skat verborge gelê. Die onfeilbare leergesag, wat Jesus aan sy kerk beloof het, het ná die dood van die apostels vir alle tye gebly in die bestuursliggaam van die opvolgers van die apostels, naamlik die Biskoppe, onder primaat van die opvolger van Petrus. " Daarmee is in wese die Heilige Skrif gelyk gestel met clie oorlewering. Openlik word ook verklaar dat daar teenoor die oorlewerings en die verkondiging deur die lewende leergesag van die kerk geen beroep op die Heilige Skrif moontlik is nie. Vir die Rooms-Katoliek kan van 'n hersiening van die Belydenis daarom nooit enige sprake wees nie. ${ }^{12}$

Tussen hierdie twee uiterstes van Biblisisme en Konfessionalisme lê 'n groot verskeidenheid van opvattings en interpretasies. Waar die behandeling daarvan egter meer inpas by ander referate laat ons dit by die enkele breë lyne.

\section{Skrifgegewens}

In hierdie referaat wat handel oor die verhouding van Skrif en Belydenis, is dit veel meer noodsaaklik en trouens ook onvermydelik om terug te gaan na die wortel van die saak naamlik die Heilige Skrif self. Navorsing moet gedoen word oor die vraag watter plek die Belydenis in die Nuwe Testament ingeneem het. Is dit so dat die skriftuurlike fiksering van die Belydenis nie eers in die vroeg Christelike kerk nie, maar reeds in die Skrif self plaasgevind het? Wat is die eintlike betekenis van die begrip homologia en in watter verband kom dit in die Nuwe Testament voor? Wat leer die Nuwe Testament aangaande die verhouding van homologia tot evaggelion? En op grond van hierdie ondersoek, wat is die verband tussen openbaring en belydenis?

Om met hierdie grondvrae na die Heilige Skrif self terug te gaan lê voor die hand. Die openbaringshistoriese metode het nog altyd goeie vrugte opgelewer. Dat studie van die historiese ontwikkeling van die vraagstuk vanaf die vroeg Christelike kerk oor die Patres, Middeleeue, Reformasie tot op vandag ook veel kan bydra tot die verstaan van die onderwerp, kan nie ontken word nie, maar die diepste en eintlike antwoorde moet ons in die Skrif self gaan soek. „Het eigenlijke motief ligt in een positieve gerichtheid op wat voor de oorspronklijke zin der homologia het belijden van de kerk in de wereld betekent". ${ }^{13}$ 


\subsection{Toenemende interesse}

Dit is besonder opvallend dat daar gedurende die twintigste eeu buitengewoon groot interesse ontwikkel het vir die ondersoek na die eerste spore van belydenisse in die Nuwe Testament. A. Seeberg $^{1 \dagger}$ het reeds aan die begin van die eeu aangetoon dat daar na die dood van Jesus in die Christelike gemeenskap 'n geloofsformule ontstaan het wat tegelykertyd die karakter gedra het van 'n onderrigs- en belydenisformule.

Verskeie Nieu-Testamentici het die aangeleentheid verder ondersoek. Bekend is die name van C. H. Dodd, ${ }^{15}$ E. Lohmeyer ${ }^{16}$ en W. Maurer. ${ }^{17}$

Maurer het die oorsprong van die Konfessie gevind in die sakramentele onderrig en praktyk van die kerk, in die doop, aanbidding en eucharistie. Hy aksentueer die feit dat die homologia 'n gemeenskaplike daad was wat saamgebind het en wat die reël van die geloof en lewe van die kerk geword het.

Wat ook nog vermelding verdien is die werke van $\mathrm{E}$. Stauffer ${ }^{18}$ en O. Cullmann. ${ }^{19}$ Eersgenoemde het veral die gebruik en gestalte van die dogmatiese formules in die vroeë Christelike kerk nagegaan, waarvan die Christologiese formules, volgens hom, verreweg die belangrikste is. Die teologiese aksent van hierdie Christusformules is geleë in ò die doksologiese, of die antagonistiese of die soteriologiese interpretasie van die Christusgeheimenis. Dit het nie alleen by die doop voorgekom nie, maar ook by sendingprediking, by planmatige onderrig en by kultiese samekomste. ${ }^{20}$

Cullman het gepoog om by die erkenning van die kompleksiteit van die omstandighede waarin die Belydenisse in die Nuwe Testament ontstaan het, die basiese formule te vind warop al die ander gebou is. Dit vind hy in die tweevoudige formule van Christus as die Seun en as die verheerlikte Here. Die omstandighede waarin dit tot vergestalting gekom het, was by die doop, die reëlmatige godsdiens, die eksorsisme, die vervolging en die polemiek teen dwaalleer. ${ }^{21}$

\subsection{Die linguïstiese ontleding van die woord homologia}

Die basiese en letterlike betekenis van die Griekse woord homologein (w.w.) of homologia (s.w.), kragtens sy samestellende dele van homo wat "dieselfde" of tegelyk en logein wat "spreek" beteken, is ooreenstemming, akkoord, erkenning. In juridiese en politieke sin het dit ook ooreenkoms of verdrag beteken.

In die Septuaginta kom die woord ongeveer 23 keer voor met uiteenlopende betekenisse terwyl dit gebruik word as Griekse vertaling van 4 Hebreeuse woorde. Die klassieke betekenis van toestem of ooreenstem of erken kom dikwels voor. Soms egter kom dit voor in die betekenis van om 'n eed af te lê of om te sweer soos in Jer. $51: 14$ en Eseg. 16:8 respektiewelik. Soms ook in saamgestelde woordvorm of om vrywillige offers te bring (Deut. 12:6), om te loof (Ps. $99: 3$ ), of selfs om sondes te bely. In elk geval besit die woordgroep 'n sterk religieuse kleur in die Septuaginta. Die kultiese 
element van instemming, belofte, lof, openlike toestemming figureer sterk.

In die vroeë Christelike literatuur is die invloed van die LXX opvallend aangesien die betekenis van lof en dank en belydenis van sonde aan die woord geheg word. 'n Paar ander klassieke betekenisse is aanwysbaar soos beloof, toestem, verklaar of openlik erken. Die belangrikste is egter dat in meeste gevalle die woord homologia en sy verbindingswaarde gebruik word om 'n oortuiging uit te spreek, d.w.s. 'n openlike belydenis wat veral betrekking het op die belydenis van Christus of die leer van die kerk.

Enigsins verrassend is die feit dat die selfstandige naamwoord homologia relatief $\mathrm{min}$ in die Nuwe Testament voorkom. Alleenlik in ses tekste: 2 Kor. $9: 13$; 1 Tim. $6: 12,13$; Hebr. $3: 1 ; 4: 14 ; 10: 23$.

Al die voorbeelde verwys na spesifieke belydenisse van geloof eerder as die daad van belydenis.

Wat die werkwoord homologein betref, kom dit meermale voor, soms in die absolute sin van konfessie (Rom. $10: 9,10$ ). Soms lui dit 'n stellingname in t.o.v. Jesus as die Christus (Joh. $9: 22,12: 42 ; 1$ Joh. $2: 22$ ), as die Here (Rom. $10: 9$; Phil. $2: 11$ ), as die Seun van God ( 1 Joh. $4: 15$; vgl. $2 \cdot 23$ ) of as die een wat in die vlees gekom het ( 1 Joh. $4: 2 ; 2$ Joh. : 7).

Homologein dui 'n getuienis en erkenning aan van mens se verhouding tot Christus (Matt. $10: 32$ ), 'n oortuiging aangaande sy persoon (Joh. $9: 22$; Rom. $10: 9$ ) of 'r spesifieke bewys van geloof (1 Joh. $4: 2 ; 2$ Joh. : 7).

As die linguistiese ontleding opgesom word, kom mens tot die volgende voorlopige resultate: Homologia verteenwoordig die instemming of consensus waarin die Christelike gemeenskap 'n eenheid gevorm het, daardie kern of hart van die basiese oortuiging wat die Christene onderskryf en openlik betuig het - die eenheidsmotief: Die homologia was die instemming en erkenning van die indiwidu se lojaliteit jeens Jesus Christus en verteenwoordig as sodanig 'n persoonlike geloofsbelydenis.

Die homologia was die belydenis aangaande Jesus met spesifieke verwysing na sy persoon en werk en was daarom Christologies.

Die homologia was 'n openlike deklarasie of getuienis van geloof, uitgespreek in publieke aanbidding (Fil. $2: 11$ ), in een of ander besondere erediens ( 1 Tim. $6: 12$ ), in prediking (Rom. 10 : $8-10$ ), of in kentrovers met Jode (Joh. $9 \cdot 22 ; 12: 42$ ), heidene (1 Tim. $6: 13$ ) of ketters (1 Joh. $4: 2,3$ ) - die forensiese $k a$ rakter dus.

Homologia sien eerder op die inhoud van die konfessie as op die daad van belydenis. Meer as eens verteenwoordig dit bepaalde formules (1 Joh. 4 : 15; Joh. $9: 22$ ), ${ }^{23}$ die inhoudelike karakter.

Polman beklemtoon die spontaniteit en imperatiewe karakter van die belydenis as hy verklaar: „Juist op grond van het feit, dat de openbaring Gods duidelik en klaar en nabij is, moet de gemeente, die met het hart gelooft, deze waarheid met de mond velijden (Rom. $10: 9$ ). Deze persoonlijke belijden is geen theoretische toestemming, geen louter verstandelijk aanvaarden en al evenmin 
een bloot moreele verplichting. Het wordt door de Heiligen Geest geëischt en gewerkt". ${ }^{24}$

\subsection{Aanverwante begrippe}

Woorde wat verband hou met homologia is die volgende: evaggelion, kerugma, didache. Oor elkeen van die woorde enkele relevante gegewens:

\subsubsection{Evaggelion:}

Die woord evaggelion wat goeie tyding of blye boodskap beteken, is 'n karakteristieke Nieu-Testamentiese woord. In die eerste tyd is die inhoud van die evangelie gesien as Jesus Christus self. Vandaar dat die werkwoord as objek het Christus (Hand. $8: 4,5$ ), of Jesus (Hand. $8: 35$ ) of Jesus en sy opstanding (Hand. $17: 18$ ) of die Seun van God (Gal. 1 $\cdot 16$ ) of Jesus die Christus (Hand. $5: 42$ ) of die Here Jesus (Hand. $11: 20$ ).

Opvallend is dit dat evangelion die woord geword het wat moes aandui die relaas of verhaal van die lewe, werk, lyde, dood en opstanding van Jesus Christus. Daarom, toe die verhaal op skrif gestel is, was dit die aangewese woord - deur Markus kortweg genoem die evangelie van Jesus Christus (Mark. $1: 1$ ).

Die eksplisiete verband tussen evaggelion en homologia tref ons aan in 2 Kor. 9 : 13 waar Paulus praat van „die onderwerping van julle belydenis aan die evangelie van Christus".

F. W. Grosheide sê hiervan: Die ware belydenis soek geen eie weë nie. Dit soek dit by die evangelie, dit betree die weg van heil, die enigste wat daar is, wil hom daardeur laat lei en aan die reël daarvan gehoorsaam wees. ${ }^{25}$

Nooit kan die belydenis dus los gemaak word van die openbaring van God nie. Daar is die allernouste verband. Die belydenis rus op die openbaring, dit is die antwoord van die mens op die openbaring. ${ }^{26}$ "The Bible is Gods voice to us, faith is the hearing of that voice, and the confession is our reply of assent to it". ${ }^{27}$

\subsubsection{Kerugma:}

Die woord kerussein en verwante woorde word in die Nuwe Testament meestal gebruik van die proklamasie aangaande Jesus Christus aan die nie-Christelike wêreld. Die woord kan beteken aankondig, proklameer, bekend maak deur 'n herout. Daar is, via die LXX, verband met die Hebreeuse woord kara wat uitroep beteken (Jes. $61: 1)$.

In die Nuwe Testament kom die werkwoord veelvuldig voor: Die boodskap van die koninkryk word aangekondig deur Johannes die Doper (Matt. $3: 1,2$ ), deur Jesus (Mark. 1:14), of deur die dissipels (Luk. 9:2) en op talle plekke in die briewe deur die apostels (2 Tim. 4 : 2; Rom. $10: 8 ; 1$ Kor. 1 : 23; Fil. 1 : 15; Hand $9: 20$ ).

Die selfstandige naamwoord kerugma kom $\min$ voor en staan in die reël in verband met Jesus Christus. 
Wat nou die verhouding van homologia en kerugma betref, kan verwys word na die duidelike uitspraak van Paulus in Rom. 10 : 8, 9: „Dit is die woord van die geloof wat ons verkondig. As jy met jou mond die Here Jesus bely en met jou hart glo dat God Hom uit die dode opgewek het, sal jy gered word".

Die homologia „Jesus is Here" en die geloof dat God Hom uit die dood opgewek het, behels die woord van die geloof wat Paulus verkondig.

Homologia en Kerugma gaan hier hand aan hand. Die homologia aangaande die Here Jesus vorm die inhoud van die kerugma.

\subsubsection{Didache:}

Die gemeente het 'n didache of leer besit wat aangesluit het by die woorde van Christus. Dit was geen onsekere, ongrypbare grootheid, maar so duidelik en vas dat die gemeente dit as 'n maatstaf moes gebruik om die prediking van die Woord daaraan te toets (Titus $1: 9)^{28}$

Waar kerugma primêr die verkondiging van die evangelie aan die nie-Christelike wêreld beteken, het didache meestal te doen met die onderrig van die Christelike geloof aan die lede van die gemeente.

Dit kan die daad sowel as die inhoud van die leer aandui. Die objek van die werkwoord kan wees die woord van God (Hand. 18: 11), die woord van die Here (Hand. 15: 35), die evangelie (Gal. $1: 2$ ), die weg van die Here (Hand. $18: 25$ ).

In elk geval is dit duidelik dat die Christelike didache of leer spoedig die status bekom het van die suiwere onderrig van die Christendom. Daarom kan Paulus in Rom. $6: 17$ praat van „die voorbeeld van die leer wat aan julle oorgelewer is", of in Titus 1: 9 van ,die betroubare woord wat volgens die leer is".

Die didache as oorlewering van die kerk was die norm vir die Christelike geloof en lewe.

Die direkte verband tussen didache en homologia blyk uit 2 Joh. : 7, 9: want hulle wat nie vashou aan die leer van Christus nie, is hulle wat nie bely dat Jesus in die vlees gekom het nie.

Die belydenis aangaande die inkarnasie was dus deel, dit was die hart van die didache. Nie alleen die apolegetiese karakter van beide blyk uit hierdie teks nie, ${ }^{29}$ maar veral die radikale teëstelling tussen bely en nie-bely. Hier skei die geeste. Hier gaan dit om lewe of dood. Hier geld die seën: hy het die Vader sowel as die Seun of die anathema: hy is 'n verleier, 'n oortreder, die Antichris. Vandaar Johannes se dringende vermaning dat die leer steeds moet rus op die sentrale belydenis dat Jesus in die vlees gekom het.

Uit al die gegewens van die Nuwe Testament is dit legitiem om te konkludeer dat die homologia 'n bepaalde vorm van Christelike tradisie was wat begin het in die tyd van Jesus se omwandeling en wat al duideliker vorm aangeneem het in die Evangelies en die Briewe. ${ }^{30}$ Die werkwoord homologein lui meer as eens ' $n$ konfessionele formule in (Joh. $9: 22$; Rom. $10: 9$, Fil. $2: 11$ ). Die selfstandige naamwoord verwys eerder na 'n spesifieke stelling of uit- 
spraak as na 'n daad van konfessie (1 Tim. $6: 12,13$; Hebr. $4: 14 ; 10: 23$ ).

Die basiese patroon van die vroegste homologia bevat twee elemente: die naam Jesus en die verbinding van die naam met 'n belangrike titel of begrip soos Christus (Joh. $1: 20 ; 1$ Joh. 2 : 22; $5: 1$ ) of Here (Rom. 10:9; Fil. $2: 11$ ) of Seun van God (Joh. $1: 3 ; 1$ Joh. $4: 15$ ).

Beide elemente moet die nodige aksent ontvang. Dit gaan in die eerste plek om Jesus wat geleef en gesterf het op aarde in die loop van die geskiedenis maar dit gaan ook daarom dat sy persoon en werk Hom laat ken het as die Christus, as die Here en as die Seun van God.

Hier klop die hart van die Christelike geloof soos wat in die Shema die hart van die Judaistiese geloof geklop het. ${ }^{31}$

By die homologia staan die persoon en werk van Jesus Christus sentraal. Soos J. Ridderbos dit uitdruk: „Jesus Christus wil beleden worden. Dat eist zijn eer als Koning, en daaraan hangs de zaligheid der zijnen". 32

\section{Historiese gegewens}

\subsection{Die Vroeë Christelike Kerk}

By die bepaling van die verhouding van Skrif en belydenis het die historiese faktor ook 'n woord mee te spreek. Die Konfessies van die vroeë Christelike kerk sowel as die Reformatoriese Konfessies wortel ongetwyfeld diep in die Skrif maar dit is net so waar dat dit ook wortel is in ' $n$ verskeidenheid van teologiese en kerklike kontroversiële beslissinge.

Aan die historiese ontwikkeling van die belydenis in die Christelike kerk van die eerste eeue en van die Reformasie word in 'n ander referaat aandag gegee. Relevant is hier uitsluitlik die funksie van die belydenis waaruit die verhouding Skrif en Belydenis blyk. Dit kan soos volg geformuleer word:

Die Belydenisskrifte was in gebruik in die vroeë kerk as leermiddel van die kategumene en wou 'n samevatting van die leer van die Skrif bied. Dit is nooit teenoor of bo die Skrif gestel nie.

Die behoefte aan 'n Belydenis is versterk deur die stryd teen die ketterye. Die valse leer moes afgewys word - dit is die negatiewe aspek van die eerste Belydenisse bv. van Nicea. Maar eenheid is gesoek in die handhawing van dieselfde Belydenis. Daarom moes die waarheid ook verdedig word. Die eerste Belydenisskrifte dra dus 'n sterk apologetiese karakter.

Die Konfessie moes diens doen as maatstaf vir die waarheid en wel by die uitleg van die Skrif. Die ketters het hulle ook beroep op die Skrifte. En so het daar gaandeweg 'n nuwe aspek bygekom, naamlik dat die Konfessie ook 'n maatstaf geword het vir die uitleg van die Skrifte.

Die vroeë Belydenisse weerspieël iets van die stryd wat binne 
die kerk oor sekere dogmas gewoed het. Dit is veral duidelik in die Belydenis van Nicea (325). Die Apostlicum as uitbreiding op die doopformule dra nie hierdie tekens so direk nie. ${ }^{33}$

\subsection{Die Reformasie}

Wat die Belydenisskrifte van die Reformatoriese tydperk betref (die drie formuliere van eenheid), hulle het, net soos die Konfessies van die eerste Christelike kerk, uitdrukking probeer gee aan dit wat die hele kerk, die een, heilige, algemene, Christelike kerk, verstaan het as die evangelie. Dit was Konfessies, eerder van die kerk as van indiwiduele teoloë. Die verskille tussen eersgenoemde en laasgenoemde is dat die eerste Christelike simbole die Konfessie van die kerk in 'n eenvoudige, direkte manier wou uitdruk, terwyl die Reformatoriese Konfessies die regte versîan van die Belydenis wou ontvou en verskans. Hulle wou die ou simbole verduidelik in die lig van nuwe probleme, ketterye en kontroverse. Daarom wou die Reformatoriese Konfessies nie die ou simbole verdring of verplaas nie. Hulle wou die ou waarhede net op 'n nuwe wyse uitdruk. Hulle wou die oue nie negeer nie maar nadruklik bevestig. Vandaar dat die ou simbole soos die Apostolicum en dié van Nicea, Chalcedon en Athanasius in die Reformatoriese Belydenisskrifte teruggevind word. Dit beklemtoon die uiterste belangrike aspek van kontinuïteit van die Belydenis, 'n aspek wat in ons tyd grootliks verwaarloos word. ${ }^{34}$

\subsubsection{Die funksie van die Belydenis by die Reformatore}

Belangrik is ook hier om na te gaan wat as die funksie van die belydenis beskou is. Is daar enige ooreenkoms met die funksie soos ons dit vasgestel het in die geskrifte van die Nuwe Testament en by die eerste Christelike kerk? Wat by die ondersoek na die belydenisuitsprake in die Nuwe Testament sowel as die vroeë Christelike simbole aan die lig gekom het, bly ook nog geld by die Reformasie. Die Belydenis moes dien as basis vir die leer van die kerk. Die drie formuliere van eenheid het tot op die huidige dag gedien as leerboeke met die oog op aflegging van geloofsbelydenis. Die Reformasie het dit soos die vroeë Christelike kerk egter nooit bo die Heilige Skrif gestel nie.

Die Belydenisskrifte het ook 'n plek gevind in die liturgie. Trouens in sy kerugmatiese arbeid in die Heidelbergse Kategismus heel vroeg reeds aangewend as leerboek. Die Konfessie moet dus, soos by die vroeë Christelike kerk, dien as maatstaf by die uitleg van die Skrif.

Die apolegetiese inslag om naamlik diens te doen by verdediging van die waarheid en self die polemiese inslag om ketterse bewegings en rigtings te bestry, is af te lei uit die inhoud.

In tyd van vervolging, en die Reformasie tydperk is daardeur gekenmerk, het die Belydenis gedien as openlike deklarasie waardeur die gelowiges en die kerk hul geloof bely het.

Die Nederlandse Geloofsbelydenis, waarvoor Guido de Bres 
per slot van rekening die martelaarsdood gesterf het, getuig, wat sy bedoeling en inhoud betref, daarvan.

Ten slotte was een van die belangrikste funksies ongetwyfeld om te dien as saambindende faktor. Nie verniet word hulle genoem Formuliere van eenheid nie. Daarom word meermale na die Konfessie verwys as akkoord van kerklike gemeenskap.

\subsubsection{Die verhouding Skrif en Belydenis by die Reformatore}

Vanweë die groot omvang van hierdie saak, juis omdat die Reformasie die spanning tussen kerkgesag en Skrifgesag laat ontvlam het, beperk ons ons tot enkele stellinge ${ }^{35}$ wat die Reformatore en die reformatoriese kerk se gemeenskaplike standpunt tipeer:

4.2.2.1. Die Heilige Skrif as die onfeilbaar geïnspireerde Woord van God is die enigste grondslag en rigsnoer van die Belydenis en Regter in alle geskille.

Die Lutherse Belydenisskrifte spreek hulle in vergelyking met die Gereformeerde Belydenisskrifte baie minder uit oor die verhouding Skrif en Belydenis. Hier is die inleiding van die Formula Concordiae egter van groot belang:

„Ons glo, leer en beken, dat die enigste reël en rigsnoer, waarvolgens alle leringe en leraars tegelyk gerig en geoordeel moet word, alleen die profetiese en apostoliese geskrifte van die Ou en Nuwe Testament is."

Hier is dus geen onduidelikheid nie: die Belydenis is gelieel en al onderworpe aan die Skrif. Alleen die Skrifgesag is absoluut.

Kom ons by die Gereformeerde Belydenisskrifte, dan word hierdie beginsel nog uitvoeriger beklemtoon: Die uitgangspunt dat die Heilige Skrif die enigste grondslag van die Belydenis is, word eksplisiet beklemtoon in die Bernese stellings van 1528, in die Geneefse Belydenis van 1536, in die Galliese Konfessie van 1559 asook in die Skotse Konfessie. ${ }^{36}$ Die uitspraak van die N.G.B. is ook goed bekend „En geen geskrifte van mense, hoe heilig hulle ook al gewees het, mag met die goddelike geskrifte gelykgestel word nie, of ook die gewoonte met die waarheid van God nie - want die waarheid is bo alles - of ook die groot mienigte of die oudheid, of die opvolging van tye of persone, of die kerkvergaderinge, verordeninge of besluite nie".

4.2.2.2. Die kerk het tog die mandaat ontvang om die leer vas te stel.

Dit is ' $n$ tweede stelling oor die verhouding Skrif en Belydenis soos dit in die Reformasie na vore kom.

Teenoor Rome moes die Reformatore die feitbaarheid en die sonde van die kerk en sy vergaderings beklemtoon. Maar daar moes ook gewaak word teen 'n ander uiterste, nl. dat die kerk weer heeltemal sy betekenis en gesag verloor. Calvyn stel dit dan ook in sy antwoord aan kardinaal Sadoletus dat die Reformasie eintlik twee vyande het, $n 1$. die dwaling van Rome, maar ook die dwaling van die Anabaptiste. By laasgenoemde verloor die kerk weer sy betekenis.

Die Skotse Konfessie verklaar bv. in art. XX duidelik dat ons 
nie ligvaardig en roekeloos moet verdoem wat deur godsalige manne in kerkvergaderings voorgestel word nie. Daar moet behoorlik ondersoek ingestel word. So 'n vergadering kan die getuienis van God se Woord deur sy besluite bevestig.

Calvyn maak in hierdie verband die mooi onderskeiding tussen Rome en die Reformasie, nl. dat eersgenoemde die kerk alleen wil laat lei deur die Gees, terwyl die Reformasie bely dat die gesag van die kerk geheel en al aan God se Woord gebonde is (Inst. IV viii 13).

Feitlik deurgaans in al die Reformatoriese Belydenisskrifte word die plek en begrip van die kerk duidelik en onomwonde gestel en in byna almal word die eerste merkteken van die ware kerk die Woord van God genoem.

Nêrens word die handhawing van een of ander Belydenisskrif as 'n merkteken van die ware kerk gehandhaaf nie.

4.2.2.3. Elke Belydenisgeskrif bly altyd aan die Heilige Skrif ondergeskik en eksaminabel. Die Belyden:s wat deur die kerk aanvaar is, het egter gesag, omdat dit met die Heilige Skrif ooreenstem en omdat dit die leer van die Skrif as 'n repitisie van die Skrif deurgee.

Die Belydenisskrif as sodanig is feilbaar en mensewerk. Hieroor het daar by die Reformatore nooit enige twyfel bestaan nie.

Wat is die misverstand eeue later verskriklik groot as met die twee woorde "quia" en "quatenus" op 'n geforseerde manier geopereer word. Die Reformasie het nooit van een van hierdie twee begrippe 'n ,Sjibbolet" gemaak nie.

Die feit wat uitstaande is, juis in die Reformasie, is dat die Belydenis nooit bo of naas nie, maar altyd onder Gods Woord staan.

Die gesag van die Belydenis (op grond daarvan dat dit ooreen. stem met God se Woord) word alreeds in die oudste Reformatoriese Konfessie bely:

Met die Disputasie van Bern in 1528 word bely: ,wat met hierdie disputasie met die goddelike, Bybelse Skrif bevestig, bewys, vasgelê, end-uit bespreek en aangeneem en daarom besluit is, dit moet ewig vasstaan". Dit word beweer op grond daarvan dat die Heilige Skrif die enigste rigsnoer is.

In die Galliese Konfessie (Franse) van 1559 word nadat in art. 5 die Skrif as die enigste geloofsreël gestel is, terstond ook bely dat die leer van die Apostels (Apostolicum), Nicea en Athanasius moet gehandhaaf word omdat hulle ooreenkom (konform) met God se Woord. (,... pource qu'ilz sont conformes á la Parole de Dieu".)

Die Skotse Konfessie 1560 beskryf sy eie Belydenis as ,goddelike waarheid wat gedra word deur die juiste outoriteit van die Heilige Skrifte" (,divini formulae").

Alhoewel die Skotse Konfessie deurgaans die outoriteit van die Heilige Skrif handhaaf, stel hy dit tog ook baie sterk: „... we firmly purpose to abide to the end in the Confession of this our Faith".

4.2.2.4. Die Reformatore het die ampsdraers van die kerk aan hulle 
belydenis gebind, omdat hulle oortuig was dat dit volgens die Heilige Skrif was.

Dit is ons vierde stelling... die binding aan die Belydenis.

Die Reformasie moes teen twee vyande stry: die kerklike hiërargie van Rome waardeur die Skrif ondergeskik geag is, maar ook teen die Anabaptiste met hulle individualisme wat geen kerkgesag wou erken nie. Teenoor hierdie Doperse rigting wat van geen Belydenis wou weet nie, het die Universiteit van Wittenberg in 1533 almal wat promoveer, onder eed verplig om niks anders te leer as die onvervalste Evangelie en die simbole van Nicea, Athanasius en die Apostolicum nie en om te volhard in die leer van die Augsburgse Konfessie. Hierdie gewoonte is heftig deur Osiander veroordeel. Melanchton probeer die besware breedvoerig weerlê.

Binding aan die Belydenis is ook reeds op die eerste Sinodes in Nederland ingevoer. Ons weet wat verder met die opkoms van die Remonstrantisme gebeur het.

\section{Tetiese resultate}

5.1. Die Heilige Skrif is as Woord van God die enigste onfeilbare en gesaghebbende norm en reël vir leer en lewe.

Uitgangspunt is. Sacra Scriptura autopistos est. Die Heilige Skrif dien homself aan as die geïnspireerde Woord van God (2 Tim. $3: 16$ ). Daarom is dit selfgeloofwaardig. Calvyn sê dat dit onveranderlik vasstaan dat... die Heilige Skrif sy geloofwaardigheid in homself het, en nie onderwerp mag word aan bewysvoeringe en redeneringe nie. ${ }^{37}$

Hierdie outopistie van die Skrif wat ook in art. 5 van die N.G.B bely word, blyk uit talle uitsprake in Ou en Nuwe Testament. ${ }^{38}$ Naas die stelling: Sacra Scriptura autopistos est geld die verdere reformatoriese stelling: Sacra Scriptura sui ipsius interpres est. Die Heilige Skrif is dus sy eie vertolker. Nie die kerklike leergesag, soos Rome verklaar nie, ook nie die vindingrykheid van die menslike rede, soos die Rassionalisme beweer het nie, maar die Skrif self moet die Skrif verklaar. ${ }^{39}$ 'n Derde relevante stelling is: Sacra Scriptura supremus iudex controversiarum est.

Hieruit volg dat die Heilige Skrif die hoogste bron en norm is, die eksklusiewe norma normans. „De Schrift is alleen norma en regula fidei et vitae". ${ }^{40}$ Geen geskrifte van mense, hoe heilig hulle ook al mag wees, mag met die goddelike Skrifte gelykgestel word nie (N.G.B. Art. VII).

5.2. Die belydenis is die antwoord van die kerk op die Woord van God

Dit is die lewende reaksie op die roepstem van die Woord en dit is gebore uit die behoefte van die geloof om hom uit te spreek. ,Als God spreekt, wil het geloof antwoorden, ik heb geloofd daarom heb ik gesproken! Het grote „Ja” van God in Jezus Christus tot ons, roept in ons wakker ons kleine maar bezielde „ja" en dat 
niet slechts als echo, want het gaat dwars door ons heen en wordt bloedwarm gegeven". 41

God roep ook trouens in die Skrif sy kerk en gelowiges op tot objektiewe en subjektiewe belydenis. ${ }^{42}$ Belydenisponering en belydenishandhawing is dus Skriftuurlik begrond en 'n necessitas tot eer van die Naam van God. Dit dien velerlei doeleindes soos uit Skrif en historie duidelik blyk.

5.3. Die Belydenisskrifte, alhoewel dit op die Skrif gegrond is en gegrond moet wees, is menslike en daarom feilbare geskrifte. ${ }^{43}$ As sodanig besit dit relatiewe gesag

Geestesleiding in belydenisponering waarborg nie onfeilbaarheid nie. ${ }^{44}$ Bavinck spreek van ,feilbaar, menschenwerk, onvolkomen uitdrukking van wat de kerk uit de Schrift als goddelike waarheid in haar bewustzijn opgenomen heeft. ${ }^{45}$ Dit wil nie sê dat die Konfessie geen gesag dra nie. Hoewel dit feilbare mensewerk is, besit dit tog gesag, afgeleide gesag, sekundêre gesag. Groen van Prinsterer het reeds beklemtoon dat die Heilige Skrif die enigste krag van God is tot vorming van die kerk in gees en waarheid. Wie egter Gods Woord alleen tot reël van prediking en onderwys in die kerk stel, gee die gelowiges met vernietiging van die kerk, prys aan die volledige heerskappy van subjektiwisme en indiwidualisme. Die bestaan van die Konfessie is geen wantroue aan die algenoegsaamheid van die Woord van God nie. Juis die vashou aan die Woord het die kerk gebring tot belydenisponering. Dit is die bewys van oorwinning, die langsaam gerypte vrug van ' $n$ ontwikkeling in Bybelondersoek en geloofskrag. Die formuliere (Konfessie) is 'n reeks van gedenktekens van die strydende kerk, onwraakbare getuienis van die geloof wat eenmaal aan die heiliges oorgelewer is, skakels van dieselfde ketting, mylpale op die weg wat afgelê is. ${ }^{46}$

„Die Reformatie erkende de Schrift als norm en bron van het dogma cler kerk. Het gezag van het kerkelijk dogma word daardoor allerminst ondergraven. Maar wel word dit gezag van z'n outonoom karakter geheel ontdaan, omdat het alleen kan bestaan in de conformiteit van het dogma met het Evangelie".47

\subsection{Die werklike relasie tussen Skrif en Belydenis}

Die Belydenis mag nooit met die Heilige Skrif gelykgestel word nie. Die belydenis staan nie naas of bo die Skrif nie maar onder die Skrif en is eksaminabel aan die Skrif wat die eksklusiewe reël is vir geloof en lewe. Die Belydenis is geen norma normans nie, dit het geen norme in homself nie, maar is norma normata, is 'n afgeleide reël of norm. Dit ontvang sy gesag en normatiewe karakter van die Heilige Skrif waaruit dit opgestel is.

Bavinck se duidelike uitspraak geld nog: „De confessie is en blijft altijd examinabel en revisibel aan de Schrift; zij is geen norma normans, maar hoogstens norma normata, geen norma veritatis, maar norma doctrinae in aliqua ecclesia recepta". 48

Die Konfessie lei die kerk en gelowige daarom altyd weer na die Skrif terug. Omgang met die Belydenis kan nooit die plek in- 
neem van die omgang met God in sy Woord nie. Daar bestaan natuurlik gevaar dat die Skrif ingeruil kan word vir die Belydenis. Die Konfessionalisme en Dogmatisme het dit ten oorvloede toe bewys. Daarteen moet altyd gewaak word. Die dogma is geen onfeilbare goddelike waarheid soos wat die Rooms-Katolisisme daarvan maak nie. Op so 'n standpunt word die deur toegemaak van 'n kritiese toetsing van die Belydenis aan die Skrif. Immers, in die Skrif spreek God, in die dogma spreek die kerk. In die Bybel gee God sy gedagtes, in die dogma dink die kerk God se openbaring na. In die kerklike Belydenis het Gods Woord deur die feilbare denke en belyde van mense heengegaan. Wie beide gelyk wil skakel, oorskry die grens wat ons spreke van God se spreke skei. ${ }^{49}$ Alleen die Heilige Skrif, nie die Belydenis nie, is outopistos. Vir die kerk het dus nie die Belydenis nie, maar die Skrif die laaste beslissende woord. Die ,sola scriptura" is die einde van alle teëspraak - dit is die reformatoriese standpunt. ${ }^{50}$ Dit bring vanselfsprekend mee dat dit in die handhawing van en binding aan die Belydenis in wese nie om die Belydenis as sodanig gaan nie, maar om handhawing van en binding aan die Skrif as eksklusief-outoritêre bron en norm vir alle tye oor lewe en lewenswandel.

Met die stelling dat die Belydenis norma normata is, word erken dat die Belydenis 'n bepaalde gesag dra. Hier is dus sprake van normatiwiteit maar dan mag die Belydenis nooit geabstraheer word van sy diepste inhoud nie wat geleë is in die norma normans, die Woord van God nie.

Die Reformasie het ongetwyfeld aan die Belydenis gesag toegeken omdat hulle oortuig was, en dit ook uitgespreek het, dat dit wat hulle in die Konfessie bely, in alles gegrond was op Gods Woord.

So word in die Formula Concordiae gesê dat die ekumeniese Belydenisse gegrond is in Gods Woord en van die Augburgse Konfessie geld, ,dat dit uit Gods Woord geneem is en daarin vas en seker gegrond is".

Binne die kerk het die Belydenis outoriteit as akkoord van kerklike gemeenskap, as uitdrukking van die geloof van die gemeente, maar dit glo en handhaaf die Belydenis alleen op grond van Gods Woord. ${ }^{51}$ In die Dordtse ondertekeningsformulier word gestel dat ,al die artikels en stukke van die leer in die Konfessie en in die Kategismus begrepe, asook die verklaring oor sommige punte van die leer in die Sinode van Dordrecht gedaan, in alles met Gods Woord ooreenkom".

Hierdie en soortgelyke ondertekeningsformuliere gaan uit van die veronderstelling dat die kerk geroepe bly om die Belydenis ten opsigte van die leer en lewenswandel van almal wat tot die kerk behoort, - konsekwent te handhaaf.

Dit is in die verband wat die onverkwiklike stryd tussen die sogenaamde quia- en quatenus-standpunt in die $19 \mathrm{e}$ eeu ontbrand het. Op die quia-standpunt word die Belydenis onderskryf omdat dit met die Skrif ooreenkom. Die quatenus-standpunt sien op 'n gebondenheid aan die Belydenis in so verre dit met die Skrif harmonieer. 
Die kontrovers het meegebring dat die twee standpunte diametraal teenoor mekaar gestel is. Die quatenus-vertolking van die binding aan die Belydenis is spoedig deur die voorstanders van die quia-standpunt beskou as 'n drastiese relativering. Aanvaarding van en binding aan die Belydenis sou dan geld slegs in soverre dit met die Skrif ooreenkom. In laasgenoemde sin is die Belydenis geen werklike Belydenis nie maar 'n ontwyking aangesien dit aan die subjektiewe oordeel van elke belyder oorlaat om te bepaal wat om te verwerp. 52

Daar is egter ' $n$ ander sin waarin die quatenus bedoel kan word en dan het dit sin. Ons het reeds die menslike en feilbare karakter van die Belydenis beklemtoon. Dit kan nooi! gelyk geskakel word met die Heilige Skrif nie. En daarom geld dit van die Belydenis as sodanig dat dit bindende karakter besit in soverre (quatenus) dit met die Skrif ooreenkom. ${ }^{53}$ Vanuit hierdie perspektief alleen is die moontlikheid van gravamina of/en revisie legitiem.

Wat die quia-struktuur betref, wys Berkouwer tereg daarop dat dit diep wortels het in wat die Nuwe Testament leer aangaande die homologia. ${ }^{54}$ Die Nuwe Testament ken naamlik 'n evidente quiastruktuur van die homologia as die beslissende antwoord van die geloof op die roep van die evangelie. Teenoor belydenis staan verloëning en belydenis veronderstel 'n geloofsbeslissing. Die diepte en erns daarvan blyk uit die feit dat dit saamhang met ewige behoud. Elke vryblywende karakter is hier uitgesluit. Van die Nieu-Testamentiese homologia geld die quia dus in radikale, in absolute sin. Dit blyk ten duidelikste uit die verband tussen homologia en evaggelion, homologia en kerugma, homologia en didache, soos vroeër aangetoon. Van eersgenoemde verhouding is vasgestel dat die homologia in ooreenstemming en onderworpe is aan die evangelie van Christus; in verband met die tweede is as resultaat van ondersoek bereik dat homologia en kerugma hand aan hand gaan; en wat die laaste verhouding betref: die belydenis aangaande die inkarnasie, soos dit blyk uit 2 Joh. 7 : 9, was die hart van die didache. In laasgenoemde teks figureer ' $n$ radikale teëstelling tussen bely en nie-bely. Dit roep of die seën op of die vloek.

Maar as die radikale quiastruktuur gel van die homologia in die Nuwe Testament, kan dit nou ook gesê word van die historiesgegroeide Konfessies van die kerk? Kan dus die binding aan die teks van die Belydenisskrifte soos ons dit vandag ken, sonder meer besien word vanuit die homologia in die Nuwe Testament wat per slot van rekening deel was van die goddelike openbaring?

Hierop moet ontkennend geantwoord word. Ten opsigte van die historiese Konfessie as sodanig geld die quatenus-struktuur. Wie dit nie erken nie, verhef die belydenis tot onfeilbare, goddelike geskrifte wat geen opening meer bied om aan die Skrif getoets te word nie. Die quatenus geld dus die objektiewe relasie tussen die Belydenis en die Skrif. Daarop is die hele moontlikheid van gravamen en revisie gebaseer. Maar verder strek die quatenus nie. Daarom kan dit nie betrek word by 'n ondertekeningsformulier nie sonder die gevaar dat dit ' $n$ subjektivering en relativering van die 
belydenis insluit nie.

Waar sprake is van handhawing van en binding aan die Belydenis, geld uitsluitlik die quia. Dit kan en moet die kerk van die ampsdraers eis. En dan geld dit nie maar van die fundamentele, terwyl die nie-fundamentele daarbuite val nie - dit sou weer die opperste subjektivisme by die agterdeur inlaat. Dit geld ook nie maar net ten opsigte van die gees en hoofsaak van die Belydenis nie.55 Dit was presies die standpunt waarop die Remonstrante gestaan het in verdediging van hul quatenus-opvatting. Met die quatenus is alleen die „kese en hoofsaak" of ,gees en hoofsaak" van die drie formuliere aanvaar. ${ }^{56}$ Maar daarmee is die Belydenis op non-aktiwiteit en non-effektiwiteit gestel. Berkouwer waarsku daarteen om nie al te spoedig ten aansien van die historiese Konfessies trou en ontrou teenoor mekaar te stel nie. Dit sou 'n litteralistiese belydenis-opvatting wees wat niks wil weet van 'n onderskeiding van belangrik en minder belangrik, sentrum en periferie in die belydenis nie. ${ }^{57} \mathrm{Hy}$ onderskei tussen sentrum en periferie, tussen sentrale belydenis en die historiese vormgewing of ekspressie en meen dat daar beslis 'n rangorde te onderskei is ten opsigte van die betrokkenheid of konsentrasie op die sentrum van die belydenis naamlik die genade van God in Christus. Van hierdie standpunt beroep Berkouwer hom op Calvyn wat gekonstateer het dat al die stukke van die ware leer nie almal van één gestalte is. Sommige is so noodsaaklik om te weet dat dit by almal ontwyfelbaar moet vasstaan as leerstukke wat eie is aan die godsdiens. As voorbeelde noem Calvyn dat daar één God is, dat Christus God is en die Seun van God en dat ons saligheid geleë is in Gods barmhartigheid. Maar dan is daar ander waaroor daar tussen die kerke verskil is, maar wat tog die eenheid van die geloof nie verskeur nie. ${ }^{58}$

Berkouwer beroep hom o.i. ten onregte op Calvyn. Calvyn het dit oor leerstukke waaroor onderskeie kerke saamstem of verskil. Dan moet daar wel onderskei word tussen fundamentele en niefundamentele leerstukke. Berkouwer betrek hierdie onderskeiding egter op die Konfessie van een kerk, wat tog die akkoord van gemeenskap is vir daardie kerk. En al sou dit ook waar wees dat sommige leerstukke in dieselfde Konfessie meer as ander gekonsentreerd is op die kern, $\mathrm{nl}$. Christus, dan word ampsdraers en lidmate nog nie onthef van die binding aan al die leerstukke nie. Indien dit die geval sou wees, werk dit tog die gevaar van relativisme en subjektivisme in die hand.

Ons antwoord ten opsigte van die vraag na die binding en handhawing van die Belydenis moet dus ten aansien van die ganse Belydenis bly: aanvaarding omdat (quia) dit konform is met die Heilige Skrif. Maar aangesien die hele Belydenis per slot van rekening mensewerk en daarom feilbaar is, gee dit elke belyer die reg om gravamen in te dien. Langs die weg kom in die gesigsveld die quatenus wat van die hele Belydenis as sodanig geld. Net so kom langs hierdie weg in sig die moontlikheid tot revisie van die belydenis. Die verskillende ondertekeningsformuliere laat ook positiewe opening daarvoor. As die Belydenis werklik altyd appel- 
label bly aan die Skrif, dan bied dit die opening tot rivisie. Van revisionisme, m.a.w. 'n voortdurende hersiening van die Belydenis soos die Remonstratisme dit voorgestaan het, is hier egter geen sprake nie..$^{59}$

Prof. dr. S. C. W. Duvenage.

(Gelewer op die Dogmatologlese Werkgemeenskapskongres, 4 Junie 1971.)

\section{BRONNELYS}

1 G. C. Berkouwer: Verontrusting en Verantwoordelijkheid, Kampen, 1960, p. 93, 94.

2 C. Augustyn: Kerk en Belijdenis, Kampen, 1969, p. 5.

3 Idem, p. 70, 71.

4 Pl. Schaff: A History of the creeds of Christendom, London 1877, p. 9.

5 E. H. Klotsche: Christian Symbolics, Iowa, 1929, p. 16.

6 H. Bavinck: Gereformeerde Dogmatiek IS, Kampen, 1967, p. 63.

7 A. D. R. Polman: Onze Nederlandsche Geloofsbelijdenis, Franeker, z.j., p. $13 \mathrm{v}$.

8 G. Toornvliet: De waarde van Dogma en Dogmatiek in Het Dogma der Kerk, Groningen, 1949. Vgl. V. Hepp: Dreigende Deformatie I, p. 29 en B. J. de Klerk: Vorme en Karakter van die Biblisisme, Kampen, 1937.

9 H. G. Groenewoud: Confessionalisme, in Christelijke Encyclopaedie II, 1957, p. 279.

10 Vgl. vir breëre bespreking P. J. Coetzee: Die binding van die Konfessie, In die Skriflig, Jrg. 4, Nr. 16, p. 9.

11 G. Toornvliet: a.w., p. 18.

12 Van der Pol: Het Christelijk Dilemma, aangehaal deur G. Toornvliet: a.w., p. 18. Vgl. A. D. R. Polman: a.w., p. 10 v.

13 G. C. Berkouwer: a.w., p. 154.

14 Der Katechismus der Urchristenheit, Leipzig, 1903.

15 C. H. Dodd: The apostolic preaching and its development, London 1936.

16 E. Lohmeyer: Kyrios Jesus, Heidelberg, 1928.

17 W. Maurer: Bekenntnis und Sakrament. Ein Beitrag zur Entstehung der christlichen Konfession, Berlin, 1939.

18 E. Stauffer: Die Theologie des Neuen Testaments, Gutersloh 1948.

19 Die ersten christlichen Glaubensbekentnisse, Zelliken Zurich, 1949.

20 E. Stauffer: a.w., p. 213, 214, 222.

21 O. Cullmann: a.w., p. 13-29.

22 Vernon $H$. Neufeld: The earliest Christian Confessions, Grand Rapids, 1963, p. 13 v.v.

23 Vernon $H$. Neufeld: a.w., p. 20.

24 A. D. R. Polman: Onze Nederlandsche Geloofsbelijdenis, p. 49. Vergelyk verder die onderzoek van Polman oor belydenisuitsprake in die Nuwe Testament in De Apostolische Kerk, Kampen, 1954, p. 194-198 waar hy tot die volgende konklusie kom: „Blijft er zo van concrete belijdenissen in de apostolische gemeenten niet veel over, daarmee word het bestaan van zulke geloofsbelijdenissen allerminst ontkend. De gemeenten bezitten van de vroegste tijden af een belijdenis, waarin zij voor zichzelf het evangelie van Christus, hetzij als een mondelinge traditie, hetzij reeds schriftelijk 
vastgelegd, hebben saamgevat. In de apostolischen prediking en in hun geschriften vonden zij tal van uitdrukkingen, korte samevattingen, heldere uiteenzettingen, die gemakkelijk als hoofdsom en toetssteen konden dienen".

F. W. Grosheide: Commentaar op het Nieuwe Testament, De tweede brief aan de Kerk te Korinthe, Kok, Kampen 19592, p. 263.

26 H. Dykstra: Die funksionering van die belydenis by prof. dr. A. A. van Ruler, Th.M.-skripsie, P.U. vir C.H.O., 1961, p. 14.

27 Aangehaal deur F. H. Klotsche: Christian Symbolics, Burlington, 1929, p. 14. Vgl. Ph. Schaff: A History of the Creeds of Christendom, London 1877, p. 5: „A creed is man's answer to Christ's question, man's acceptance and interpretation of God's Word".

28 Polman: a.w., p. 49.

29 Neufeld: a.w., p. 28, 29.

30 Neufeld: a.w., p. 140 v. Vgl. Polman: a.w., p. 48.

31 Vgl. E. Stauffer: a.w., p. 219, 220; Neufeld: a.w., p. 34-41.

32 J. Ridderbos: De Heilige Geest en het belijden der Kerk, in De Heilige Geest, Kampen, 1949, p. 30 ?.

$33 \mathrm{Vgl}$. R. Seeberg: Textbook of the history of doctrines, Grand Rapids, 1964. Ph. Schaff: A history of the Creeds of Christendom, London, 1877; J. N. D. Kelly: Early Christian doctrines, London, 19602. A. D. R. Polman: De apostolische kerk, p. 215-217.

34 Athur C. Cochrane: Reformed Confessions of the 16th Century, Westminster Press, Philadelphia, 1964, p. 26.

35 A. D. R. Polman: Onze Nederlandsche Geloofsbelijdenis, p. 62 v.v.

36 A. D. R. Polman: Onze Nederlandsche Geloofsbelijdenis, p. 63.

37 J. Calvyn: Instr. I, VIII, 5; Vgl. Kenneth S. Kantzer: Calvin and the Holy Scriptures, in Inspiration and Interpretation, Michigan, 1957, p. 123; $R$. Bijlsma: Schriftuurlijk Schriftgezag, Nijkerk, 1959, p. 290; A. D. R. Polman: a.w., p. 227.

38 Vgl. S. C. W. Duvenage: Die gesag van die Heilige Schrift, Potchefstroom, 1967, p. $26-29$.

39 Luthers Werke, Weimarer Ausgabe, 7, 97, 23-29; J. Calvyn: Komm. 2 Petrus 1 : 20.

40 H. Bavinck: Gereformeerde Dogmatiek, Kampen, 19675, p. 63.

41 G. Toornvliet: De waarde van dogma en Dogmatiek, in Het dogma der kerk, Groningen, 1949, p. 25.

42 A. D. R. Polman: a.w., p. 46 v.

43 Vgl. N.G.B., Art. VII.

44 J. Ridderbos: a.w., p. 317.

45 H. Bavinck: a.w., IV, p. 401, 402.

46 Aangehaal deur A. D. R. Polman: a.w., p. 32.

47 G. C. Berkouwer: Uit de geskiedenis van het dogma, in Het dogma kerk, p. 32 .

48 H. Bavinck: Geref. Dogm. IV, p. 401. Vgl. A. D. R. Polman: Belijdenisschrift, in Christelijke Encyclopedie I, Kampen, 1956, p. 551.

49 G. Toornvliet: a.w., p. 11 en 17.

50 Vgl. P. J. Coetzee: Die binding van die konfessie, In die Skriflig, Jrg. 4, Nr. 16, p. 20.

51 H. Bavinck: Gereformeerde Dogmatiek I, p. 63. Vgl. A. D. R. Polman: Belijdenisschrift, Christelijke Encyclopaedie I, Kampen, 1956, p. 552. 


\section{In die Skriflig}

52 E. H. Klotsche: a.w., p. 16.

53 A. D. R. Polman: Onze Nederlandsche Geloofsbelijdenis I, p. 65.

54 G.. C. Berkouwer: a.w., p. 140

55 C. Augustyn: Kerk en Belijdenis, p. 69, H. Volten: Rondom het belijden der kerk.

56 A. D. R. Polman: Onze Geloofsbelijdenis, p. 85-87.

57 G. C. Berkouwer: a.w., p. 145.

58 J. Calvyn: Institusie IV, 1, 12.

59 A. D. R. Polman: a.w., p. 99-102. Vgl. G. C. Berkouwer: a.w. p. 131-136 waar hy veral Kuyper se standpunt breed bespreek. 